\title{
Analysis of benthic macroinvertebrates and biotic indices to evaluate water quality in rivers impacted by mining activities in northern Chile
}

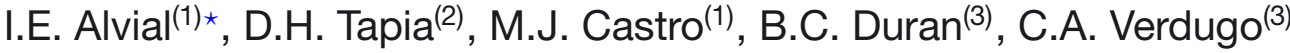 \\ Received May 14, 2012 \\ Revised November 14, 2012 \\ Accepted November 26, 2012
}

Key-words: macroinvertebrates, biotic indices, multivariate analysis, semiarid region

\section{ABSTRACT}

Catchments in the semiarid regions are especially susceptible to environmental perturbation associated with water scarcity, hydrological variations and overuse by anthropogenic activities. Using multivariate analysis to relate environmental and biological data, and diversity and biotic indices (ChBMWP, ChIBF), we analyzed the macroinvertebrate composition of 12 rivers of the semiarid region of northern Chile. A non-metric multidimensional scaling for macroinvertebrate taxa and a principal component analysis for environmental variables strongly separated upstream sites (e.g. Vacas Heladas and Malo Rivers), which presented low $\mathrm{pH}$ and high dissolved metal concentrations, from other sites. Effectively, CCA showed that metals and low $\mathrm{pH}$, associated with the altitudinal gradient, determined the distributional patterns of macroinvertebrates in the Elqui catchment. The causes of these particular conditions could be related to geological processes and human impact. The biotic indices applied to the sampling sites corroborated and reflected these characteristics, with La Laguna and Turbio Rivers showing a diverse macroinvertebrate community and moderate to good water quality, and the Claro River showing favorable conditions for the development of aquatic biota, indicating its better quality relative to other stations. To the middle and low part of the basin, a change in the composition of the community was observed, with species that suggest an impact by an increase in organic matter, due to agricultural activities and urban settlements concentrated in this area. Our results suggest that macroinvertebrate taxa in northern Chile may be exceptional species, adapted to unfavorable geochemical conditions, and emphasize the need for protection of the semiarid basins of the region.

\section{RÉSUMÉ}

L'analyse des macroinvertébrés benthiques et indices biotiques pour évaluer la qualité de l'eau dans les rivières touchées par les activités minières dans le nord du Chili

Mots-clés : Les bassins versants des régions semi-arides sont particulièrement sensibles aux macroinvertébrés, perturbations de l'environnement associées à la rareté de l'eau, aux variations indices hydrologiques et à la surexploitation par les activités anthropiques. Utilisant une analyse multivariée pour relier les données environnementales et biologiques, la diversité et des indices biotiques (ChBMWP, ChIBF), nous avons analysé la

(1) Center for Advanced Studies in Arid Zones

(2) Instituto Interdisciplinario de Neurociencias, Universidad de Valparaíso

(3) Universidad de La Serena

* Corresponding author: ingrid.alvial@ceaza.cl 
biotiques, analyse multivariée, région semi-aride composition des macroinvertébrés des 12 rivières de la région semi-aride du nord du Chili. Une mise à l'échelle multidimensionnelle non métrique pour des taxons de macroinvertébrés et une analyse en composantes principales des variables environnementales, séparent fortement les sites amont (par exemple Vacas Heladas et rivières Malo), qui présentent un $\mathrm{pH}$ faible et des concentrations élevées de métaux dissous, issus d'autres sites. En effet, la CCA a montré que les métaux et le $\mathrm{pH}$ faible associés au gradient altitudinal, déterminent les modes de distribution des macroinvertébrés dans le bassin versant Elqui. Les causes de ces conditions particulières pourraient être liées à des processus géologiques et à l'impact humain. Les indices biotiques appliqués aux sites d'échantillonnage, corroborent et reflètent ces caractéristiques, avec les rivières La Laguna et Turbio montrant une communauté de macroinvertébrés diversifiée et plutôt à eau de bonne qualité, et la rivière Claro montrant les conditions favorables au développement des organismes aquatiques, donnant la meilleure qualité par rapport aux autres stations. Pour la partie moyenne et basse du bassin, un changement dans la composition de la communauté a été observé, avec des espèces qui suggèrent un impact d'une augmentation de la matière organique, en raison des activités agricoles et des agglomérations urbaines concentrées dans ce secteur. Nos résultats suggèrent que les taxons de macroinvertébrés dans le nord du Chili peuvent être des espèces exceptionnelles, adaptées à des conditions géochimiques défavorables, et mettre l'accent sur la protection des bassins semi-arides de la région.

\section{INTRODUCTION}

In drylands, streams and rivers exert an important role in the survival strategies of the human populations and their economic activities. These regions are especially susceptible to environmental perturbation associated with water scarcity, hydrological variations and overuse by anthropogenic activities (Maltchik and Medeiros, 2006). The semiarid region of northern Chile concentrates high population densities, and the main economic activities are agriculture and mining (DGA, 2004). These anthropogenic activities and other natural factors (orogenesis processes, volcanic activity and geology) have strongly influenced the aquatic ecosystems in this region (Oyarzún et al., 2006, 2007).

In the Elqui basin, two centuries of intensive mining and metallurgical operations have left a heritage of abandoned mines and piles of mineral wastes, and consequently a strong impact on water quality (Oyarzún et al., 2003). The mining and geothermal activity in the Elqui Valley has contributed to an increase in heavy metals such as $\mathrm{As}, \mathrm{Cu}$ and $\mathrm{Pb}$ in the waters of the Elqui River (Pizarro et al., 2010; Espejo et al., 2012). Because of these aforementioned impacts, the vulnerability of these rivers to climatic fluctuations and their importance as water supply for human needs make it essential to implement monitoring plans for the protection of water resources in rivers of northern Chile (Vila and Molina, 2006).

Macroinvertebrates have been considered as a successful model for biomonitoring mainly due to: (a) their sedentary nature, which facilitates spatial analyses of pollution effects, (b) the sensitivity of many common species, documented for different types of pollutants, and (c) the long life cycles of the same species, which can be used to trace pollution effects over longer periods (Bonada et al., 2006). However, the environmental monitoring in catchments of northern Chile has been hitherto addressed only by physical-chemical parameters of water quality, and barely with biological criteria (Vila and Molina, 2006). Nevertheless, several ecological studies that include the adaptation and application of macroinvertebrates biotic indices have been conducted in Mediterranean rivers of central and southern Chile (Figueroa et al., 2003, 2005, 2007; Córdova et al., 2009; Mancilla et al., 2009). Only recently have the governmental agencies of Chile been encouraged to use ecological indicators in monitoring programs and environmental legislation. However, the use of biological criteria for assessing water quality in Chile requires the collection of information in different biogeographic regions. Therefore, we have developed biological surveys from 2007 to date, in the main basins of northern 


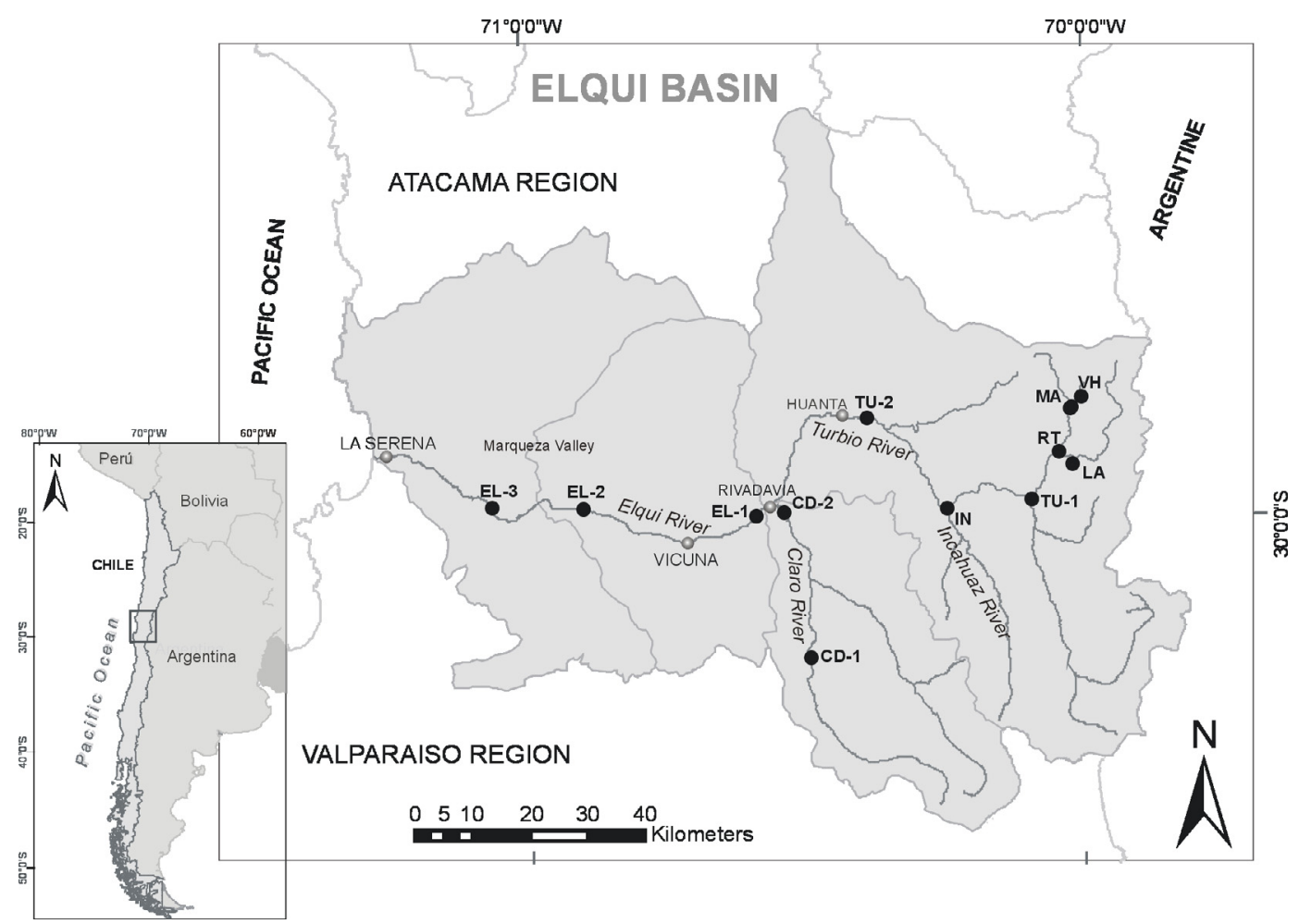

\section{Figure 1}

Geographical locations of the rivers studied. River systems were encoded as follows: Elqui (EL), Claro (CD), Turbio (CD), Incahuaz (IN), Del Toro (RT), La Laguna (LA), Malo (MA) and Vacas Heladas (VH).

Chile, Huasco, Elqui and Limarí. All of them are semiarid basins, with little knowledge on the ecology of their macroinvertebrate communities (Jara, 2002; Donoso, 2007; Figueroa et al., 2009) and on how these communities are affected by the mining activities operating in this region. Hence, the objective of this work was to evaluate the ecological status of the Elqui River by analyzing its macroinvertebrate fauna and employing biotic indices (ChBMWP and ChIBF) adapted by Figueroa et al. (2007) for rivers in central-southern Chile. Macroinvertebrate communities were used since they are recognized by the European Water Framework Directive as the most important organisms for assessing the integrity of biological communities in the assessment of ecological status (Alvarez, 2010). For this reason, we expected that macroinvertebrate communities reflect the impact of anthropogenic activities along the basin of the Elqui River. Finally, the information reported here will allow the implementation of regular plans of environmental monitoring using biological indices not only for the Elqui River, but potentially for all the semiarid basins of northern Chile.

\section{MATERIAL AND METHODS}

\section{> STUDY AREA}

The Elqui watershed $\left(29^{\circ} 18^{\prime}-30^{\circ} 26^{\prime} \mathrm{S}\right.$ of latitude) covers an area of $9794 \mathrm{~km}^{2}$, and its main river is the Elqui River, which flows westward from the Andes Mountains to the Pacific Ocean (Figure 1). The main tributaries of the Elqui River are the Turbio and Claro Rivers. The Turbio River drains the high mountains in the northern side of the main basin with an average flow of $6.48 \mathrm{~m}^{3} / \mathrm{s}$, and comprises three other tributaries, Toro, La Laguna and Incahuaz Rivers. On the other hand, the Claro River, which drains the high mountains in the southern side, has an average flow of $3.9 \mathrm{~m}^{3} / \mathrm{s}$, the Cochiguaz River being its main tributary (Cepeda and Novoa, 


\section{Table I}

Sampling sites studied in the Elqui basin. A ranking for sites was established according to the altitude (downstream samples <1000 m a.s.l.; middle samples 1000-2000 m a.s.l. and upstream samples $>2000 m$ a.s.l.).

\begin{tabular}{|l|c|c|c|}
\hline Rivers & Code & Classification & Elevation (m a.s...) \\
\hline Vacas Heladas & VH & U & 2551 \\
\hline Malo & MA & U & 2558 \\
\hline Del Toro & RT & U & 2091 \\
\hline La Laguna & LA & U & 2116 \\
\hline \multirow{2}{*}{ Turbio } & TU-1 & U & 2144 \\
& TU-2 & $\mathrm{M}$ & 1222 \\
\hline Incahuaz & $\mathrm{IN}$ & $\mathrm{M}$ & 1674 \\
\hline \multirow{2}{*}{ Claro o Derecho } & $\mathrm{CD}-1$ & $\mathrm{M}$ & 1971 \\
& $\mathrm{CD}-2$ & $\mathrm{D}$ & 872 \\
\hline \multirow{3}{*}{ Elqui } & $\mathrm{EL}-1$ & $\mathrm{D}$ & 793 \\
& $\mathrm{EL}-2$ & $\mathrm{D}$ & 431 \\
\cline { 2 - 4 } & $\mathrm{EL}-3$ & $\mathrm{D}$ & 205 \\
\hline
\end{tabular}

2006). The Elqui catchment has a mixed and exorheic hydrological regime type, where the flows depend on the rainfall in winter and snow/glacial melt in spring (Sanchez and Morales, 1990).

The climatic characteristics of this arid region include periodic water scarcity, a product of the precipitation variability, which is manifested in long and persistent dry periods. Thus, the average rainfall is low $(120 \mathrm{~mm} /$ year) and very variable from one year to another, with a clear altitude gradient: $83 \mathrm{~mm} /$ year on the coast, $86 \mathrm{~mm} /$ year at $640 \mathrm{~m}$ above sea level and $200 \mathrm{~mm} /$ year at $3750 \mathrm{~m}$ above sea level (Cepeda, 2008). Events of precipitation occur during April to September (fall-winter), June being the wettest month. However, precipitation may increase two- or threefold in years affected by the El Niño phenomenon. The temperature fluctuates from $0{ }^{\circ} \mathrm{C}$ in the high mountains ( $>3000 \mathrm{~m}$ a.s.I.) to $16^{\circ} \mathrm{C}$ on the coast $(<1500 \mathrm{~m}$ a.s.I.) (DGA, 2004). The vegetation in the Elqui basin is characterized by a coastal scrub-shrub steppe of Acacia caven Molina, Andean scrub and Andean steppe (Cepeda, 2008). The geology of the Elqui basin is dominated by calc-alkaline intermediate volcanic rocks intercalated with sedimentary rocks. These rocks host hydrothermal ore deposits of a number of metals, although only copper, gold, silver, and to a lesser extent manganese, have had economic importance, representing $36 \%$ and $60 \%$ of the country's total production (Oyarzún et al., 2003; Cepeda and Novoa, 2006).

The Elqui basin concentrates more than $25 \%$ of all the large mines (annual production $=>3$ million ton $\mathrm{yr}^{-1}$ ) of gold and copper in the central-northern region of Chile (Pizarro et al., 2010). El Indio mining district was a large mine located above Vacas Heladas and Malo Rivers, that began a closure plan in 2002. This mining district contributed to strongly increasing heavy metals in these headwater rivers (Oyarzún et al., 2003, 2006). Currently, more important mining operations are San Gerónimo, Talcuna and Linderos districts, the latter located in Marquesa Valley (Figure 1).

The land use of urban type in the basin is reduced, reaching 343 hectares, equivalent to $0.03 \%$ of the total area, and is mainly concentrated in the city of La Serena and the towns of Vicuña and Andacollo. Agriculture occupies 27,713 hectares, equivalent to $3 \%$ of the total area, and is concentrated mainly between the Almendral locality and the city of La Serena, although it is distributed in small areas in the middle of the basin (e.g. Claro and Cochiguaz riversides) (DGA, 2004).

\section{> ENVIRONMENTAL AND BIOLOGICAL SAMPLING}

Twelve sampling sites from the high mountains to the sea level were monitored in October 2011 (Table I). Three sampling sites were established in the Elqui River (EL-1 in the Algarrobal location; EL-2 in the Almendral location and EL-3 in the Las Rojas location); two 
sampling sites were established in the Claro River (CD-1 in the Alcohuaz location and CD-2 in the Rivadavia location); and one sampling site in the Incahuaz River (IN) near the Balala location. Four sampling sites were established near the Juntas del Toro location: one in the EI Toro River (RT), one in the Malo River (MA), one in the Turbio River (TU-1) and one in the Vacas Heladas River $(\mathrm{VH})$. The remaining two sampling sites were located in the La Laguna River (LA) in the Nueva Elqui location and the Turbio River (TU-2) in the Huanta location (Figure 1).

At each sampling point temperature $\left({ }^{\circ} \mathrm{C}\right), \mathrm{pH}$, conductivity $\left(\mu \mathrm{S} \mathrm{cm}{ }^{-1}\right)$, total dissolved solids (ppm) and dissolved oxygen ( $\mathrm{mg} \mathrm{L}^{-1}$ ) were recorded. Temperature, $\mathrm{pH}$, conductivity and total dissolved solids were measured with a WD-35630-69 pH m, and dissolved oxygen was measured with a YST/Cole Parmer DO200 oximeter.

Heavy metal concentration data were provided by the National Water Directorate of Chile (DGA) from data of their water quality monthly monitoring program (unpublished data). Water samples for these analyses were taken during October 03-07, 2011, and the collection and preservation of water samples followed the NCh 411/6 Of. 96 protocols (INN, 2003).

Macroinvertebrate monitoring was performed first by a visual inspection of a $50-\mathrm{m}$ stretch of the river channel to identify the different habitats or substrates. Therefore, substrates were classified as bryophytes, submerged spermatophyte, stones $(25-250 \mathrm{~mm})$, coarse gravel $(2.5-25 \mathrm{~mm})$ or sand/silt with diameter $<2.5 \mathrm{~mm}$. Then, the sampling began in the most abundant substrate according to their representativeness (\%). The macroinvertebrate sampling was quantitative, using a standard Surber sampler (surface $500 \mathrm{~cm}^{2}$, mesh size $500 \mu \mathrm{m}$ ), as suggested by Barba et al. (2010), who concluded that a $0.5-\mathrm{mm}$ mesh was sufficient for most biomonitoring purposes with macroinvertebrates. For each sampling point, 6 replicates were obtained. A total of 42 total samples were sieved, stored in plastic bottles $(500 \mathrm{ml})$ and preserved in $70 \%$ ethyl alcohol. In the laboratory, samples were sorted using a $250-\mu \mathrm{m}$ mesh sieve and taxonomically identified to the family level (except for Hydrozoa, Hydracarina and Oligochaeta), to compare them under the same hierarchical rank (Figueroa et al., 2007). The identification was performed using a stereoscopic microscope at 40X, following Fernández and Domínguez (2001), Thorp and Covich (2001), Tachet et al. (2003), Camousseight (2006), and Dominguez and Fernández (2009).

\section{> DATA ANALYSIS}

Physical-chemical variables were explored by a principal component analysis (PCA) based on a correlation matrix between samples. Data were logarithmically transformed and normalized. This ordination analysis is relevant to obtain detailed site-specific information to describe reference conditions for the fauna.

One-way analysis of similarity (ANOSIM) was used to test differences in macroinvertebrate composition between sample groups (downstream, middle and upstream samples). ANOSIM is a hypothesis testing procedure that uses Bray-Curtis dissimilarity. This procedure uses a $(\mathrm{R})$ test based on the difference between the average of all the rank dissimilarities between objects between groups and the average of all the rank dissimilarities between objects within groups. Differences between groups would be estimated by $R$ values greater than zero, where objects are more dissimilar between groups than within groups (Clarke and Gorley, 2006). A nMDS analysis was conducted to evaluate ordination patterns of sites according to biological data (using the Bray-Curtis similarity index and square root transformations of abundance data). These analyses were performed with the Primer 6 software (Plymouth Routines in Multivariate Ecological Research). Variation in macroinvertebrate data was directly compared with the environmental variables and biotic indices by a Canonical Correspondence Analysis (CCA) after ensuring that this technique was appropriate. This was verified by running a Detrended Correspondence Analysis (DCA) on the macroinvertebrate data to ensure a unimodal rather than a linear distribution. The unimodal assumption of DCA is accepted if the gradient length of the first axis is greater than 2.5 SD (Ter Braak and Smilauer, 2002). Relative abundances of macroinvertebrates were square root-transformed and the influence of rare species on the 
Table II

Water quality classes based on the biotic indices ChBMWP (Biological Monitoring Working Party) and ChIBF (Index Biotic Family), modified from Figueroa et al. (2007).

\begin{tabular}{|l|c|c|c|}
\hline Class & ChBMWP & ChIBF & Significance \\
\hline I & $>100$ & $0.0-3.8$ & Undisturbed \\
\hline II & $61-100$ & $3.8-4.6$ & Moderately disturbed \\
\hline III & $36-60$ & $4.6-7.3$ & Disturbed \\
\hline IV & $16-35$ & $6.1-7.3$ & Very disturbed \\
\hline $\mathbf{V}$ & $<15$ & $7.3-10.0$ & Strongly disturbed \\
\hline
\end{tabular}

analysis was reduced by checking the downweighting of the rare species in the CCA ordination. Only families that presented relative abundance $>1 \%$ were incorporated in this analysis. Due to the high collinearity found in environmental variables, a stepforward selection procedure was employed to select the variables. This analysis ranked the environmental variables in order of their importance in explaining the variation in species data. Only the significant variables $(P<0.05)$ tested by Monte Carlo simulations within the model were incorporated in the overall analysis. All these analyses were performed with the CANOCO software V. 4.5.

\section{$>$ BIOTIC INDICES}

The macroinvertebrate community was characterized by several diversity indices: species richness (number of species in each sample, S); total abundance (number of individuals in each sample, $N$ ); and the Shannon-Wiener diversity index $\left(\mathrm{H}^{\prime}\right)$. In addition, to evaluate the environmental quality of the 12 rivers studied, the Biological Monitoring Working Party Index (BMWP) and Family Biotic Index (FBI) were applied. The BMWP index (Armitage et al., 1983 ) is a qualitative biological index that assigns a score to each family, and the sum of all family scores represents the final BMWP score. High BMWP scores denote a low degree of environmental pollution (Table II).

The FBI index (Hilsenhoff, 1988) assigns tolerance values to each family and is calculated according to the formula IBF $=1 / N\left(n i^{*} t i\right)$, where $n i$ is the number of individuals in a family, $t i$ is the tolerance value assigned to the family, and $N$ is the total of individuals in the sample.

These indices were successfully adapted by Figueroa et al. (2007) for Mediterranean rivers for the south-central area of Chile. These authors included new families of macroinvertebrates (those present in Chilean rivers) and carried out extensive bibliographic research to assign the tolerance values of these families. Although there are complex statistical tools to relate environmental conditions to macroinvertebrates and determine tolerance values (Chessman, 2003), this method requires extensive and long-term surveys; however, in Chile databases and biological surveys are scarce. For this reason, work of this type is a first approach to the adaptation of biotic indices for Chilean rivers. The use of ChBMWP and ChIBF (denomination used by Figueroa et al., 2007) in semiarid rivers of northern Chile consisted of including the families found in the rivers studied and assigning them tolerance values obtained from the literature (Prat et al., 2000; Mackie, 2001; Figueroa et al., 2003, 2007).

\section{RESULTS}

\section{> HABITAT CHARACTERIZATION}

The rivers located upstream presented average river widths of less than $4 \mathrm{~m}$ and depths of about $30 \mathrm{~cm}$. These rivers were characterized by sparse riparian vegetation and benthic algae, and the dominant substrates were stones and coarse gravel. In the middle of the basin, an increase in riparian vegetation and benthic algae was observed. The riverside of the Claro River showed native vegetation and clear waters, suggesting low human intervention in this river. The Claro River also showed a greater depth in the river channel. The sampling sites located in the low part of the basin showed high densities of aquatic vegetation and benthic 


\section{Table III}

Means and ranges of major environmental variables for downstream samples $<1000 \mathrm{~m}$ a.s.l., middle samples (1000-2000 $m$ a.s.l.) and upstream samples (>2000 m a.s.l.).

\begin{tabular}{|c|c|c|c|}
\hline Variables & Downstream & Middle samples & Upstream \\
\hline Conductivity $\left(\mu \mathrm{S} \cdot \mathrm{cm}^{-1}\right)$ & $399.4(279-689)$ & $393.5(136.7-735)$ & $1075.7(586-2450)$ \\
\hline Total dissolved solids (ppm) & $266.5(139-344)$ & $195.6(68.7-368)$ & $538.2(293-1230)$ \\
\hline $\mathrm{pH}$ & $7.83(7.7-8.1)$ & $7.73(7.7-7.8)$ & $5.52(3.2-7.9)$ \\
\hline D.O. (ppm) & $7.25(4.22-9.04)$ & $2.8(1.43-5.56)$ & $5.1(2.96-7.26)$ \\
\hline Temperature $\left({ }^{\circ} \mathrm{C}\right)$ & $16.1(14.6-18.1)$ & $14.6(12.6-16.3)$ & $7.44(1.2-13.9)$ \\
\hline $\mathrm{Cl}^{-}\left(\mathrm{mg} \cdot \mathrm{L}^{-1}\right)$ & $20.5(6.02-30.1)$ & $15.4(5.2-10.03)$ & $79.2(31.4-121.7)$ \\
\hline $\mathrm{Al}\left(\mathrm{mg} \cdot \mathrm{L}^{-1}\right)$ & $0.63(0.25-2.26)$ & $2.37(0.15-6.41)$ & $24.8(1.6-57.9)$ \\
\hline As $\left(\mathrm{mg} \cdot \mathrm{L}^{-1}\right)$ & $0.03(0.007-0.08)$ & $0.04(0.001-0.11)$ & $0.33(0.054-0.69)$ \\
\hline $\mathrm{Cu}\left(\mathrm{mg} \cdot \mathrm{L}^{-1}\right)$ & $0.13(<0.02-0.48)$ & $0.38(0.04-1.09)$ & $2.7(<0.02-5.67)$ \\
\hline $\mathrm{Fe}^{+}\left(\mathrm{mg} \cdot \mathrm{L}^{-1}\right)$ & $0.45(<0.02-1.55)$ & $1.92(0.39-5.03)$ & $16.8(0.93-43.9)$ \\
\hline $\mathrm{Mn}\left(\mathrm{mg} \cdot \mathrm{L}^{-1}\right)$ & $0.11(<0.02-0.39)$ & $0.37(<0.02-1.05)$ & $3.93(0.06-6.94)$ \\
\hline $\mathrm{Zn}\left(\mathrm{mg} \cdot \mathrm{L}^{-1}\right)$ & $0.04(<0.01-0.15)$ & $0.14(0.03-0.39)$ & $1.47(0.01-3.5)$ \\
\hline
\end{tabular}

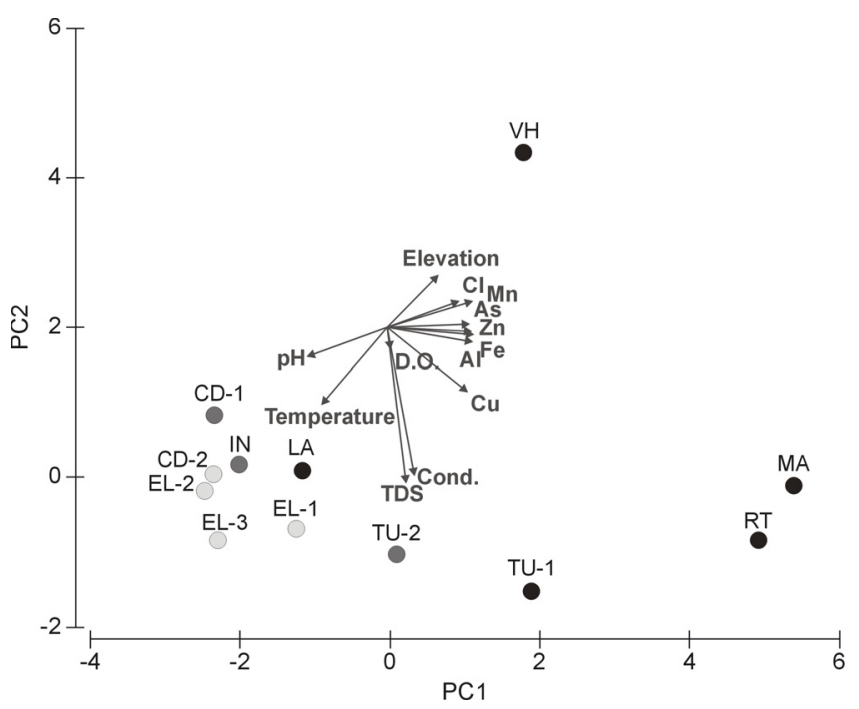

\section{Figure 2}

Principal component analysis ordination for twelve site samples in Elqui basin. Sites in black circles are located upstream (>2000 $\mathrm{m}$ of elevation); dark gray circles are sites located in the middle stream $(1000-2000 \mathrm{~m})$ and clear gray circles are sites collected downstream $(<1000 \mathrm{~m})$. Acronyms of taxa in Table IV.

algae. These sampling sites are located near main towns, therefore the riparian vegetation is replaced by introduced vegetation and the presence of pools and dams is common.

Rivers located above 2000 m a.s.l., such as Turbio, La Laguna, Del Toro, Malo and Vacas Heladas, presented high values of conductivity and total dissolved solids. Similarly, these systems showed acidic $\mathrm{pH}$ and low temperatures (Table III) in comparison with rivers located in the middle and low parts of the catchment (e.g. Elqui and Claro Rivers). Heavy metal concentration data indicated high concentrations of $\mathrm{Al}, \mathrm{Fe}, \mathrm{As}, \mathrm{Fe}$ and $\mathrm{Mn}$ in upstream sites (Table III). In downstream sites, metal concentrations decreased below the detection limit in the closest sites to towns.

The principal component analysis conducted with the 13 variables (described in Table III and including elevation) showed that factors one and two explained $61.9 \%$ and $17.4 \%$ of the variance, respectively. The first PCA axis was determined positively by dissolved metals (Zn: 0.346, Al: $0.345, \mathrm{Mn}: 0.344$ and Fe: 0.337$)$ and negatively correlated with $\mathrm{pH}(-0.323)$. The second axis was determined negatively by TDS $(-0.623)$ and Cond. $(-0.597)$. In the twodimensional biplot (Figure 2), the sites located in the upper part of the catchment (VH, MA, RT 
and TU-1) were distributed to the right in the biplot, whereas the sites located in the middle (TU-2, IN-10, LA and CD-1) and in the low parts of the catchment (CD-2, EL-1, EL-2 and EL-3) were sorted to the left.

\section{> MACROINVERTEBRATE COMMUNITIES}

A total of 13479 individuals from 38 taxa were identified. The most abundant families (relative abundances $>10 \%$ ) were Chironomidae, Ceratopogonidae, Leptoceridae, Elmidae, Hydropsychidae and the order Oligochaeta (Table IV). The family Chironomidae was highly abundant in almost all sampling sites and was dominant in rivers located at high altitudes (i.e., Del Toro, Vacas Heladas and Malo Rivers). Oligochaeta was abundant in La Laguna and Elqui Rivers. Besides, the family Hydropsychidae was present in several sites, and was more abundant in the Claro River, where Leptoceridae was also abundant. The families Ceratopogonidae and Elmidae were abundant in the Turbio River, but Elmidae dominated the communities located above $2000 \mathrm{~m}$ a.s.I. Elqui and Claro Rivers presented the highest species richness, whereas Malo and Vacas Heladas headwaters showed the lowest number of species. La Laguna and Elqui Rivers (EL-1) in the Algarrobal location showed the highest number of individuals, whereas the Malo and Vacas Heladas headwaters showed a low number of individuals. According to the Shannon-Wiener diversity index, the Claro River showed a highly diverse macroinvertebrate community (Table V).

The ANOSIM analysis showed that macroinvertebrate composition between groups of samples (downstream, middle and upstream samples) showed no differences (Global test: $R=$ $0.14, p=0.154$ and Pairwise test: middle-down $R=0.037, p=0.429$; middle-upper $R=0.272, p=0.125$; down-upper $R=0.11, p=0.238$ ). However, when faunistic data were used for nMDS (Figure 3), the upstream sites were separated from the other sampling sites. The dendrogram of the cluster superimposed onto nMDS grouped the sampling sites into 2 groups according to the macroinvertebrate composition (Bray-Curtis $=20$ ). These groups were: Group 1= CD-1, CD-2, LA, EL-1, EL-2, EL-3, TU-2, IN, and Group 2 = TU-1, RT and MA; $\mathrm{VH}$ was classified as an outlier.

\section{> BIOTIC INDICES}

ChBMWP index values classified the Vacas Heladas River as a strongly disturbed habitat; Malo (MA), Del Toro (RT) and Incahuaz (IN) Rivers as very disturbed habitats; the Turbio River as a disturbed habitat; La Laguna and Elqui Rivers as moderately disturbed habitats, and the Claro River as a very good quality or undisturbed habitat (Table V). The ChBMWP index is qualitative and is highly related to richness and diversity of taxa. For this reason, the good quality found in Claro River coincides with the high abundance and richness described for this site. On the other hand, the ChIBF index classified the sites located in Incahuaz (IN) and Vacas Heladas (VH) as strongly disturbed habitats; the sites located in Malo, Del Toro, La Laguna, Turbio and Elqui Rivers as very impacted habitats; and the Claro River (CD-2) and Turbio River (TU-1) as moderately disturbed or good water quality.

\section{> RELATIONSHIP BETWEEN BIOLOGICAL AND ENVIRONMENTAL DATA}

Canonical Correspondence Analysis based on relative abundance of macroinvertebrates explains $63.6 \%$ of variance within the dataset (cumulative percentage variance of species data, first four CCA axes). The variance explained by the CCA is best reflected by metal concentrations and elevation (Figure 4). The most important gradient is composed of $\mathrm{pH}$ and total dissolved solids, which are closely correlated with the first CCA axis. The second CCA axis 


\section{Table IV}

Relative abundance of macroinvertebrates identified in Elqui (EL), Claro (CD), Turbio (TU), Incahuaz (IN), Del Toro (RT), La Laguna (LA), Vacas Heladas (VH) and Malo (MA) Rivers. Acronyms in parenthesis.

\begin{tabular}{|c|c|c|c|c|c|c|c|c|c|c|c|c|}
\hline & $E L-3$ & EEL-2 & EEL-1 & CD-2 & CD-1 & TU-1 & TU-2 & IN & RT & LA & \begin{tabular}{|l|l|} 
VH \\
\end{tabular} & MA \\
\hline Diptera & & & & & & & & & & & & \\
\hline $\begin{array}{l}\text { Athericidae } \\
\text { (Ather) }\end{array}$ & & & 0.1 & & & 2.8 & & & & 0.1 & & 6.7 \\
\hline $\begin{array}{l}\text { Ceratopogonidae } \\
\text { (Cerat) }\end{array}$ & 0.1 & & 6.5 & & & 2.8 & 59.2 & 50.3 & & & & \\
\hline $\begin{array}{l}\text { Chironomidae } \\
\text { (Chiron) }\end{array}$ & 14.1 & 77.7 & 76.1 & 11.6 & 19.7 & 22.5 & 31.9 & 42.9 & 76.5 & 32.5 & 100 & 66.7 \\
\hline $\begin{array}{l}\text { Dolichopodidae } \\
\text { (Dolic) }\end{array}$ & 0.1 & & & & & & & & & & & \\
\hline $\begin{array}{l}\text { Empididae } \\
\text { (Empi) }\end{array}$ & 0.5 & 0.8 & 0.2 & & & 1.4 & 0.2 & & 8.8 & 0.4 & & \\
\hline $\begin{array}{l}\text { Ephydridae } \\
\text { (Ephyd) }\end{array}$ & & & & & & & & & & & & 6.7 \\
\hline $\begin{array}{l}\text { Limoniidae } \\
\text { (Limo) }\end{array}$ & 0.7 & 0.7 & & 1.3 & & & & & & & & \\
\hline $\begin{array}{l}\text { Simuliidae } \\
\text { (Simu) }\end{array}$ & 0.7 & 3.7 & 0.1 & 0.6 & 0.3 & & 0.2 & 0.8 & & & & \\
\hline $\begin{array}{l}\text { Tipulidae } \\
\text { (Tipul) }\end{array}$ & 0.4 & 0.4 & & 0.3 & 0.1 & & & & & & & \\
\hline Ephemeroptera & & & & & & & & & & & & \\
\hline $\begin{array}{l}\text { Baetidae } \\
\text { (Baeti) }\end{array}$ & & 5.7 & 7 & 18.7 & & 1.4 & 4.4 & 0.3 & 2.9 & 1.5 & & \\
\hline $\begin{array}{l}\text { Leptophlebiidae } \\
\text { (Leptop) }\end{array}$ & & & & 6 & 7.8 & & & & & 5 & & \\
\hline $\begin{array}{l}\text { Collembola } \\
\text { (Collem) }\end{array}$ & 0.3 & 0.1 & & & & & & & & & & \\
\hline $\begin{array}{l}\text { Megaloptera } \\
\text { Corydalidae } \\
\text { (Cory) }\end{array}$ & & & & 0.1 & & 2.8 & & & & & & \\
\hline $\begin{array}{l}\text { Lepidoptera } \\
\text { Pyralidae } \\
\text { (Pyral) }\end{array}$ & & & & & & & 0.2 & & & & & \\
\hline Trichoptera & & & & & & & & & & & & \\
\hline $\begin{array}{l}\text { Glossosomatidae } \\
\text { (Glosso) }\end{array}$ & & & & & & & & & & & & \\
\hline $\begin{array}{l}\text { Helicophidae } \\
\text { (Heli) }\end{array}$ & & & & & 5.1 & & & & & & & \\
\hline $\begin{array}{l}\text { Hydroptilidae } \\
\text { (Hydropt) }\end{array}$ & 0.1 & 2.5 & 0.4 & & 1.2 & & & & & & & \\
\hline $\begin{array}{l}\text { Hydrobiosidae } \\
\text { (Hydrob) }\end{array}$ & & & 1 & 1.4 & 1.6 & 2.8 & & & 2.9 & 0.4 & & \\
\hline $\begin{array}{l}\text { Hydropsychidae } \\
\text { (Hydrops) }\end{array}$ & 0.9 & 5.8 & 4.2 & 35.6 & 12.8 & 7.0 & 0.2 & 2.6 & & 3.8 & & \\
\hline $\begin{array}{l}\text { Leptoceridae } \\
\text { (Leptoc) }\end{array}$ & & & & 0.7 & 14.3 & & & & & 0.3 & & \\
\hline $\begin{array}{l}\text { Sericostomatidae } \\
\text { (Seric) }\end{array}$ & & & & & 9.5 & & & & & & & \\
\hline Coleoptera & & & & & & & & & & & & \\
\hline $\begin{array}{l}\text { Elmidae } \\
\text { (Elmi) }\end{array}$ & & 0.1 & & 14.2 & 4.3 & 56.3 & 0.8 & & & 13.9 & & 6.7 \\
\hline $\begin{array}{l}\text { Hydrophilidae } \\
\text { (Hydroph) }\end{array}$ & & & 0.3 & & & & & & & & & 6.7 \\
\hline $\begin{array}{l}\text { Scirtidae } \\
\text { (Scirt) }\end{array}$ & & & & & & & 0.2 & & 2.9 & & & \\
\hline Dytiscidae (Dytis) & 0.1 & & & & & & 0.2 & & & & & \\
\hline
\end{tabular}


Table IV

Continued.

\begin{tabular}{|c|c|c|c|c|c|c|c|c|c|c|c|c|}
\hline & EL-3 & ELL-2 & ELL-1 & CD-2 & CD-1 & TU-1 & TU-2 & \begin{tabular}{|l|} 
IN \\
\end{tabular} & \begin{tabular}{|l|} 
RT \\
\end{tabular} & LA & VH & MA \\
\hline $\begin{array}{l}\text { Odonata } \\
\text { Gomphidae } \\
\text { (Gomph) } \\
\text { Aeshnidae } \\
\text { (Aesh) }\end{array}$ & & $\begin{array}{l}0.3 \\
0.1\end{array}$ & & & & & & & & & & \\
\hline $\begin{array}{l}\text { Tricladida } \\
\text { Dugesiidae } \\
\text { (Duge) }\end{array}$ & 1 & 0.9 & & 1.3 & & & & & & & & \\
\hline $\begin{array}{l}\text { Gastropoda } \\
\text { Hydrobiidae } \\
\text { (Hydrobii) } \\
\text { Physidae } \\
\text { (Physi) }\end{array}$ & $\begin{array}{l}0.7 \\
2.7\end{array}$ & & & 0.2 & 0.5 & & & & & & & \\
\hline $\begin{array}{l}\text { Acari } \\
\text { (Aca) }\end{array}$ & 0.1 & 0.2 & 1.1 & 0.1 & & & 0.8 & & 2.9 & 0.1 & & \\
\hline $\begin{array}{l}\text { Crustacea } \\
\text { Hyalellidae } \\
\text { (Hyal) } \\
\text { Ostracoda } \\
\text { (Ostra) } \\
\text { Decapoda } \\
\text { (Deca) }\end{array}$ & $\begin{array}{l}1.8 \\
0.7 \\
0.1\end{array}$ & 0.1 & & $\begin{array}{l}2.9 \\
0.4\end{array}$ & 0.2 & & & & & 0.1 & & \\
\hline $\begin{array}{l}\text { Mollusca } \\
\text { Sphaeriidae } \\
\text { (Spha) }\end{array}$ & 0.3 & & & & 0.3 & & & & & & & \\
\hline $\begin{array}{l}\text { Annelida } \\
\text { Glossiphoniidae } \\
\text { (Glossi) } \\
\text { Oligochaeta } \\
\text { (Olig) }\end{array}$ & 74.4 & 0.5 & 0.2 & 3.3 & 15 & & 0.7 & $\begin{array}{l}0.3 \\
2.6\end{array}$ & & 38.5 & & \\
\hline $\begin{array}{l}\text { Nematoda } \\
\text { (Nema) }\end{array}$ & & 0.4 & 2.1 & 0.1 & & & 1.2 & 0.3 & 2.9 & 3.1 & & \\
\hline
\end{tabular}

Table $V$

Diversity index (R, richness, $N$, total abundance and $H^{\prime}$, Shannon-Wiener) and biotic indices with class quality in parentheses for each sampling site in the Elqui basin.

\begin{tabular}{|c|c|c|c|c|c|c|}
\hline Rivers & Sites & ChBMWP & ChlBF & $\mathbf{R}$ & N & $H^{\prime}$ \\
\hline Malo & $\overline{\mathrm{MA}}$ & 26 (IV) & 6.2 (IV) & 6 & 15 & 1.17 \\
\hline Vacas Heladas & $\overline{\mathrm{VH}}$ & $2(\mathrm{~V})$ & 7 (IV) & 1 & 1 & \\
\hline Del Toro & RT & 32 (IV) & 6.45 (IV) & 7 & 34 & 0.94 \\
\hline La Laguna & $\overline{L A}$ & 84 (II) & 6.49 (IV) & 19 & 2670 & 1.55 \\
\hline \multirow[b]{2}{*}{ Turbio } & TU-1 & 49 (III) & 4.47 (II) & 9 & 71 & 1.36 \\
\hline & TU-2 & 47 (III) & 6.20 (IV) & 13 & 593 & 1.04 \\
\hline Incahuaz & IN & 30 (IV) & 6.43 (IV) & 8 & 380 & 0.98 \\
\hline \multirow{2}{*}{ Claro } & CD-1 & $106(\mathrm{I})$ & 5.01 (III) & 20 & 2009 & 2.27 \\
\hline & CD-2 & 109 (I) & $4.47(I I)$ & 22 & 2228 & 1.96 \\
\hline \multirow{3}{*}{ Elqui } & EL-1 & 76 (II) & $6.43(\mathrm{IV})$ & 16 & 2686 & 0.99 \\
\hline & EL-2 & 73 (II) & $6.45(\mathrm{IV})$ & 17 & 1808 & 0.98 \\
\hline & EL-3 & 73 (II) & $7.69(\mathrm{~V})$ & 20 & 984 & 1.03 \\
\hline
\end{tabular}




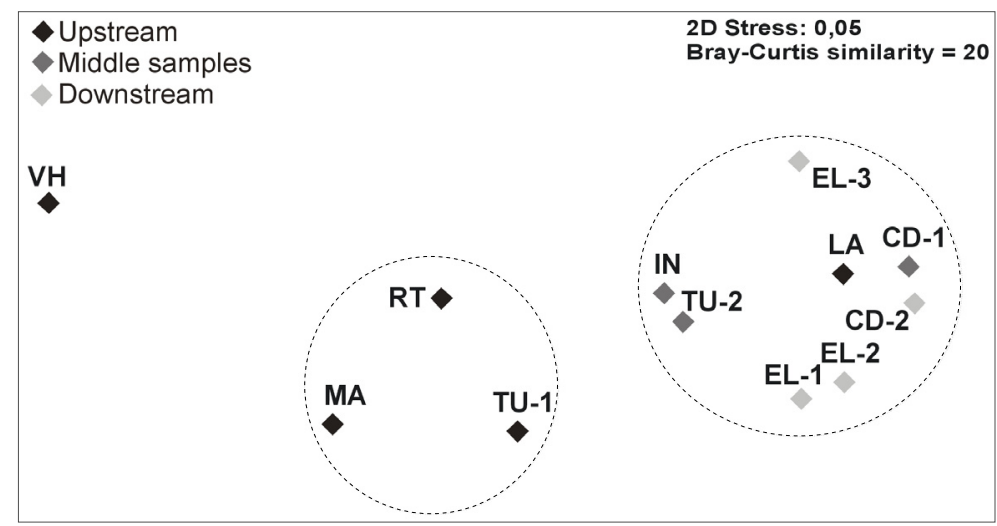

Figure 3

Non-metric multidimensional scaling (nMDS) in macroinvertebrate composition, with cluster groups superimposed (Bray-Curtis $=20$ for biological data).

is mainly a temperature gradient decreasing from upstream to downstream samples. Eigenvalues (0.1 to 0.3 ) indicated regular dispersion of the species along the axis (Ter Braak and Smilauer, 2002). The species-environment correlation was $>0.88$ and an unrestricted Monte Carlo permutation test indicated that the first and second axes were significant $(P$ value $<$ 0.05).

Upstream sites in Malo and Turbio (TU-1) Rivers, with acidic pH, and high concentrations of dissolved solids and metals, are located in the upper right quadrant in Figure 4. Representative families in these sites were Ephydridae (Ephyd), Hydrophilidae (Hydroph) and Athericidae (Ather). On the contrary, sampling sites with alkaline waters and low metal concentrations, such as sites in the Elqui River (El-3 and El-2), and the Claro River (CD-1 and CD-2), are located in the upper left quadrant. These sites concentrated a high diversity and abundance of macroinvertebrates such as Fam. Baetidae (Baeti), Leptoceridae (Leptoc), Hydropsychidae (Hydrops), Sericostomatidae (Seric) and Helicophidae (Heli). In the bottom right quadrant, sites distributed along the whole basin that showed high concentrations of dissolved oxygen and moderate concentrations of metals are located. In these sites (VH, RT, IN, El-1 and Tu-2), the macroinvertebrate community was mainly represented by Fam. Ceratopogonidae (Cerat), Scirtidae (Scirt) and Chironomidae (Chiro).

\section{DISCUSSION}

The Elqui watershed (northern Chile) constitutes a highly contaminated system, associated with the regional geology and hydrothermal (mineralizing) processes, and mining activities at high altitude (>4000 $\mathrm{m}$ above sea level) (Oyarzún et al., 2003; Pizarro et al., 2010). In fact, monthly monitoring of water quality conducted by the National Water Directorate (DGA) evidenced high concentrations of $\mathrm{Fe}, \mathrm{Al}$ and $\mathrm{As}$ in upstream rivers. Therefore, the objective of this work was to study the distributional patterns of macroinvertebrates in relation to these environmental characteristics, by multivariate analyses and biotic indices (ChBMWP; ChIBF).

\section{> NATURAL CONDITIONS OF THE BASIN ASSOCIATED WITH MACROINVERTEBRATES}

The relationships between biological and environmental data collected in this survey and evaluated by a CCA ordination suggested that the particular physical-chemical characteristics (high metal concentrations and low $\mathrm{pH}$ ) could be determining the spatial distributional patterns of macroinvertebrates in the Elqui basin, evidencing the impacts of environmental conditions on the aquatic communities. The sites located upstream, mainly Vacas Heladas, Malo, 


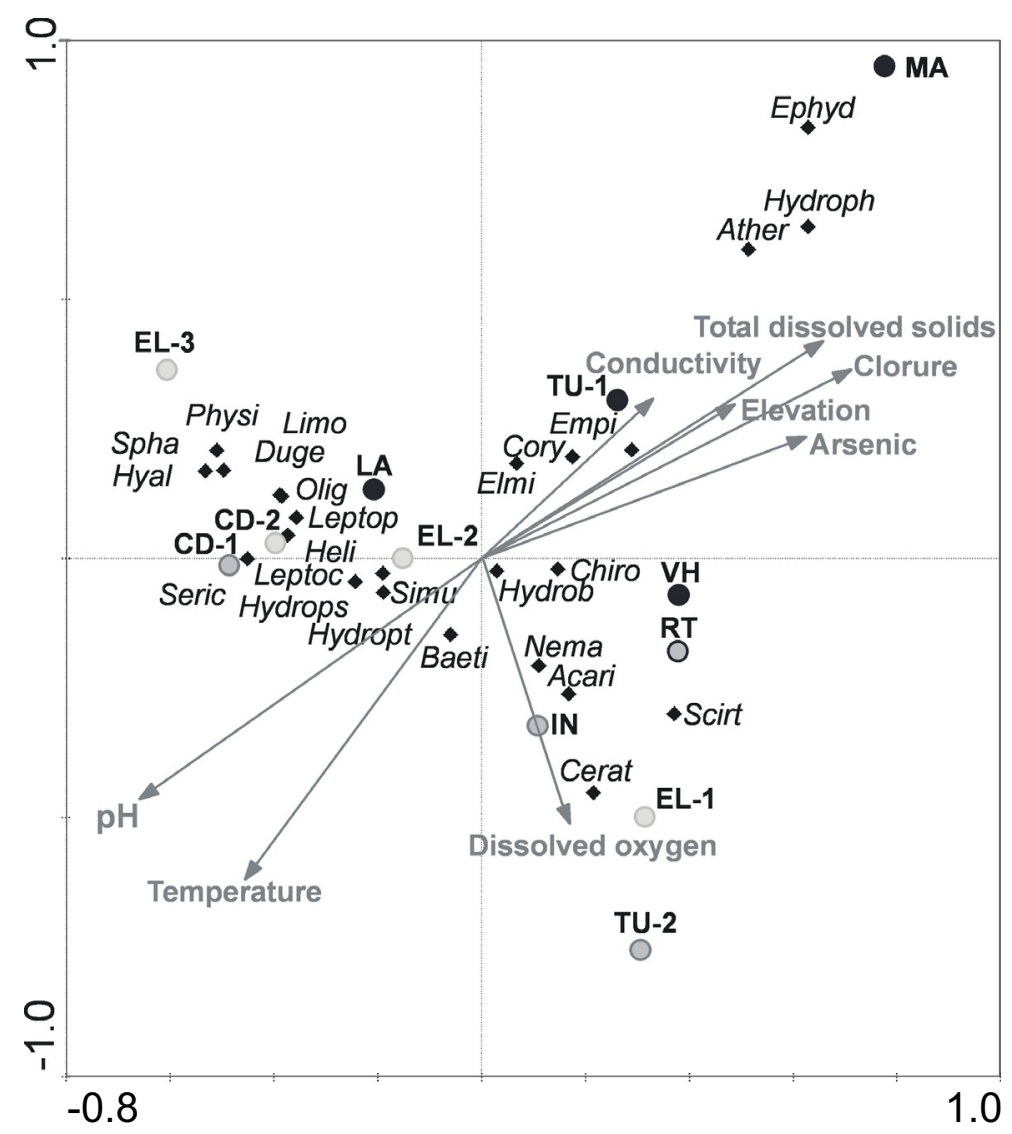

\section{Figure 4}

Canonical correspondence analysis (CCA) ordination plots for sites, environmental variables and species. Sites in black circles are located upstream (>2000 m of elevation); dark gray circles are sites located in the middle stream (1000-2000 m) and clear gray circles are sites collected downstream $(<1000 \mathrm{~m})$. Acronyms of taxa in Table IV.

Turbio and Del Toro Rivers, showed the lowest abundance and richness of macroinvertebrate taxa. The Malo River showed markedly low pH values (mean of 4.5) and the macroinvertebrate communities were represented by Fam. Ephydridae, Hydrophilidae and Athericidae. In Del Toro and Laguna Rivers, located about 2000 m a.s.l., with still high concentrations of dissolved metals such as $\mathrm{Al}$, $\mathrm{Cu}$ and $\mathrm{Fe}$, a macroinvertebrate community formed by mayflies and dipteran larvae was described.

In the upper part of the Huasco River, another semiarid basin located to the north of the Elqui basin, low-pH waters and natural high metal concentrations have also been registered (Strauch, 2009). Specifically, El Estrecho River, located at $3831 \mathrm{~m}$ a.s.l. in the headwaters of the Huasco basin, showed average pH values of 4.1. However, mayfly (Leptophlebiidae) and dipteran (Chironomidae, Ephydridae, Empididae and Limoniidae) taxa were reported (Alvial et al., in press). All these data may suggest that some macroinvertebrate taxa in northern Chile could have evolved tolerance to acidic waters. Previous studies (Jara, 2002; Donoso, 2007) described endemic species of invertebrates present in the Elqui River, such as Smicridea chilensis Navas (Trichoptera: Hydropsychidae) and Penaphlebia chilensis Eaton (Ephemeroptera: Leptopblehiidae). This endemism could be potentially extended to several other taxa found in upstream sites of the Huasco and Elqui catchments; which, consequently, may suggest the idea that they could also be adapted to acidic waters, a condition usually reported for the water in northern rivers of Chile. However, more studies are required to confirm this assumption and to describe the potential singularities of Chilean macroinvertebrate communities. 
Nevertheless, in the Vacas Heladas River ( $\mathrm{pH}$ 5.2) only a single individual (Chironomidae) was registered. Chironomidae species have been described as tolerant to high metal concentrations and acidic waters in rivers (Kiffney and Clements, 1994; Cranston et al., 1997), but with only a handful of tolerant species that attain high densities in such environments, despite the low richness. Nevertheless, gradual decreases in $\mathrm{pH}$ cause severe reductions in densities (Tokeshi, 1995).

Our results showed that only in the Claro River was it possible to find favorable conditions for macroinvertebrates, mainly mayflies, coleopterans and caddisflies. This river concentrated high richness and abundance of taxa, and according to CCA ordination, the representative taxa in this river were the Fam. Hydropsychidae, Baetidae and Leptophlebiidae, known as indicators of good water quality (Tachet et al., 2003).

In the low part of the Elqui basin, as abiotic conditions changed, the benthic community became more abundant and earthworms (Order Oligochaeta) dominated the communities, possibly associated with impacts related to the proximity to major towns (Vicuña and La Serena) and the agricultural activities concentrated in the middle and low parts of the watershed, since earthworms are known as indicators of high organic content in waters. In fact, monthly monitoring performed by the National Water Directorate of Chile (DGA, 2004) reported diffuse pollution from cattle-grazing areas and discharges of pesticides from intensive cultivation of table grapes, in Turbio and Incahuaz Rivers.

The application of biotic indices based on macroinvertebrate communities amply reflected the impacts described for the Elqui basin. Therefore, the ChBMWP and ChIBF indices showed a strongly disturbed habitat in the Vacas Heladas River, a very disturbed class in samples located in the middle of the basin (Del Toro, Incahuaz and Turbio Rivers), and moderately disturbed in samples located in Claro and La Laguna Rivers. Additionally, the Elqui River sites were classified as being disturbed according to both biotic indices. This probed the efficiency of macroinvertebrate-based biotic indices in assessing river water quality in the Elqui basin. Nonetheless, ChBMWP is easy to apply but is qualitative, making it suitable for poorly studied streams (Figueroa et al., 2007). In contrast, ChIBF can be a better tool to be applied in northern Chile rivers, but it is necessary to adjust its accuracy through experimental surveys in the study area.

\section{$>$ RELATIONSHIP BETWEEN MINING ACTIVITIES AND MACROINVERTEBRATES IN THE BASIN}

El Indio mining district is located in the Andean headwaters of the Elqui River basin. The initiation of a full-scale mining project in El Indio (1980-2002) led to an increase in As values in Del Toro, Turbio and Elqui Rivers, that largely exceed the USEPA regulations for drinking water (Oyarzún et al., 2006). However, it is worth noting that these authors also mentioned the importance of the geological characteristics (e.g. high mineralization) in determining acidic waters and metals dissolved in the waters of these rivers. Arsenic is an element that can be closely associated with hydrothermal systems of the acid-sulfate type leading to the formation of precious metal epithermal deposits (Pizarro et al., 2010). However, studies performed in streams that originate from the Vacas Heladas River in the altitudinal range from 3920 to 3970 m above El Indio mining district reported the presence of mayflies and caddisflies (Cepeda and Morales, 2006). These taxa drastically decreased in the portion of the river draining this mining district. Therefore, our results may suggest that the mining impact could be stronger than natural processes in affecting the benthic fauna, in line with the reports by Petrin et al. (2007), who showed through a meta-analytic approach based on 60 datasets, that macroinvertebrate species richness declines three times more rapidly with increasing acidity when the water acidity is of human origin (by the release of acidifying substances and metal-rich drainage) than when it is natural.

The effects of impacts related to mining activities on aquatic invertebrates are relatively well known (e.g., Smolders et al., 2003; Harding, 2005; Pond et al., 2008; Van Damme et al., 2008). Despite the fact that the effects of metal toxicity on invertebrates are complex and vary from 
taxon to taxon (Harding, 2005), large increases in certain ions can disrupt water balance and ion exchange processes and cause organism stress or death of some less tolerant groups (Pond et al., 2008). For instance, reports by Pond et al. (2010) indicate that some mayflies are highly sensitive to increases in ionic strength. To some mayflies, toxicity to acid mine discharges and alkaline surface mining effluents might result from exposure or ingestion of trace heavy metal compounds, or interference with osmoregulation and respiration by the fast increase in conductivity and component ions (Clements, 2004).

The results found in this work highlight the ecological importance of the Elqui basin for assessing new macroinvertebrate species adapted to extreme conditions in semiarid basins. Together with the endemism described for some species in other works, they emphasize the need for an urgent protection of these aquatic ecosystems, urgently requiring the implementation of an extensive biomonitoring program of human activities taking place in the basin. Furthermore, the impact of pollution in rivers of the semiarid region of northern Chile may be potentially greater than in other countries due to the aridity of the Chilean mining region, which would reduce the available water for human consumption and agricultural use. Moreover, the scarcity of water resources in the study region may become even more critical if global climate changes reduce local precipitation and affect the hydrological cycles (Cepeda and Novoa, 2006), being a potential threat to the functioning of aquatic ecosystems.

Finally, the patterns observed in macroinvertebrate communities reported here can be used for the development of biotic indices specific to the northern region of Chile, and for the generation of species-specific hypotheses about the effects of environmental variables on biodiversity.

\section{ACKNOWLEDGEMENTS}

This research was supported by the Ministry of the Environment of Chile (ID N612228-4LE11).

\section{REFERENCES}

Alvarez M., Barquin J. and Juanes J., 2010. Spatial and seasonal variability of macroinvertebrate metrics: Do macroinvertebrate communities track river health? Ecol. Indic., 10, 370-379.

Armitage P., Moss D., Wright and Furse M., 1983. The performance of a new biological a water quality score system based on macroinvertebrates over a wide range of unpolluted running-water sites. Wat. Res., 17, 333-347.

Barba B., Larrañaga A., Otermin A., Basaguren A., and Pozo J., 2010. The effect of sieve mesh size on the description of macroinvertebrate communities. Limnetica, 29, 211-220.

Bonada N., Prat N., Resh V. and Statzner B., 2006. Developments in aquatic insect biomonitoring: a comparative analysis of recent approaches. Ann. Rev. Entomol., 51, 495-523.

Camousseight A., 2006. Estado de conocimiento de los efemerópteros de Chile. Gayana, 70, 50-56.

Cepeda J., 2008. Los sistemas naturales de la cuenca del río Elqui, Región de Coquimbo: Vulnerabilidad y cambio del clima. Ediciones Universidad de La Serena, La Serena.

Cepeda J. and Morales M., 2006. Limnología del humedal Tambo-Puquíos. In: Cepeda J. (ed), Geoecología de los Andes Desérticos, La Alta Montaña del Valle del Elqui, Ediciones Universidad de La Serena, La Serena, 415-471.

Cepeda J. and Novoa J., 2006. La Cordillera Altoandina del Valle del Elqui. In: Cepeda J. (ed), Geoecología de los Andes Desérticos, La Alta Montaña del Valle del Elqui, Ediciones Universidad de La Serena, La Serena, 41-63.

Chessman B., 2003. New sensitivity grades for Australian river macroinvertebrates. Mar. Freshw. Res., $54,95-103$.

Clarke K. and Gorley R., 2006. PRIMER v6: user manual/tutorial. PRIMER-E, Plymouth.

Clements, WH., 2004. Small-scale experiments support causal relationships between metal contamination and macroinvertebrate community response. Ecol. Appl., 14, 954-967. 
Córdova S., Gaete H., Aranguiz F. and Figueroa R., 2009. Evaluación de la calidad de las aguas del estero Limache (Chile central), mediante bioindicadores y bioensayos. Lat. Am. J. Aquat. Res., 37, 199-209.

Cranston P., Copper P., Hardwick R., Humphrey C. and Dostine P., 1997. Tropical acid streams - the chironomid (Diptera) response in northern Australia. Fresh. Biol., 37, 473-483.

Dirección General de Aguas, 2004. Diagnostico y clasificación de los cursos y cuerpos de agua según objetivos de calidad, cuenca del río Elqui- Dirección General de Aguas, Santiago, Chile.

Domínguez E. and Fernández H., 2009. Macroinvertebrados bentónicos sudamericanos. Sistemática y biología. Fundación Miguel Lillo, Tucumán.

Donoso K., 2007. Macroinvertebrados bentónicos y la evaluación de la calidad del agua en los ríos Elqui y Cachapoal. Memoria de título para Biólogo con mención en Medio Ambiente. Facultad de Ciencias de la Universidad de Chile, Santiago.

Espejo L., Kretschmer N., Oyarzún J., Meza F., Núñez J., Maturana H., Soto G., Oyarzo P., Garrido M., Suckel F., Amezaga J. and Oyarzún R., 2012. Application of water quality indices and analysis of the surface water quality monitoring network in semiarid North-Central Chile. Environ. Monit. Assess., 184, 5571-5588.

Fernández H. and Domínguez E., 2001. Guía para la determinación de los artrópodos bentónicos sudamericanos. Ediciones de la Universidad Nacional de Tucumán, Tucumán.

Figueroa R., Valdovinos C., Araya E. and Parra O., 2003. Macroinvertebrados bentónicos como indicadores de calidad de agua del sur de Chile. Rev. Chil. Hist. Nat., 76, 275-285.

Figueroa R., Ruiz V., Encina F. and Palma A., 2005. Simplificación en el uso de macroinvertebrados en la evaluación de la calidad de las aguas en sistemas fluviales. Interciencia, 30, 770-774.

Figueroa R., Palma A., Ruiz V. and Niell X., 2007. Comparative analysis of biotic indexes used to evaluate water quality in a Mediterranean river of Chile: Chillán River, VIII Region. Rev. Chil. Hist. Nat., 80, $225-242$.

Figueroa R., Suarez M., Andreu A. and Ruiz V., 2009. Caracterización ecológica de humedales de la zona semiárida en Chile Central. Gayana, 73, 76-94.

Harding J., 2005. Impacts of metals and mining on stream communities. In: Moore T., Black A., Centeno J., Harding J. and Trumm D. (eds)., Contaminants in New Zealand, Christchurch, New Zealand, 343-357.

Hilsenhoff W., 1988. Rapid field assessment of organic pollution with a family-level biotic index. J. Amer. Ent. Soc., 7, 65-68.

Instituto Nacional de Normalización, 2003. Norma Chilena 411/6 Of.96 Calidad del agua-muestreo-Parte 6: Guía para el muestreo de ríos y cursos de agua, Santiago, Chile.

Jara C., 2002. Evaluación de la existencia de insectos bioindicadores de la calidad del agua en zonas ritrónicas y potámicas de tres ríos de la zona semiárida de Chile. Memoria de Título para Biología mención en Medio Ambiente. Facultad de Ciencias, Universidad de Chile, Santiago.

Kiffney P. and Clements W., 1994. Effects of heavy metals on a macroinvertebrate assemblage from a Rocky Mountain stream in experimental microcosm. J. N. Am. Benthol. Soc., 13, 511-523.

Mackie G., 2001. Applied aquatic ecosystem concepts. Kendall/Hunt Publishing Company, Dubuque, lowa.

Maltchik L. and Medeiros E., 2006. Conservation importance of semi-arid streams in north-eastern Brazil: implications of hydrological disturbance and species diversity. Aquat. Conser., 16, 665-677.

Mancilla G., Valdovinos C., Azócar M., Henriquez M. and Figueroa R., 2009. Aproximación multimétrica a la evaluación de la calidad del agua en cuencas con diferentes niveles de intervención antrópica. Interciencia, 34, 857-864.

Oyarzún J., Maturana H., Paulo A. and Pasieczna A., 2003. Heavy metals in stream sediments from the Coquimbo Region (Chile): Effects of sustained mining and natural processes in a semi-arid Andean basin. Mine Wat. Env., 22, 155-161.

Oyarzún R., Lillo J., Oyarzún J., Higueras P. and Maturana H., 2006. Strong metal anomalies in stream sediments from semiarid watersheds in Northern Chile: when geological and structural analysis contribute to understanding environmental disturbances. Inter. Geol. Rev., 48, 1-12.

Oyarzún R., Oyarzún J., Lillo J., Maturana H. and Higueras P., 2007. Mineral deposits and Cu-ZnAs dispersion-contamination in stream sediments from the semiarid Coquimbo Region, Chile. Environ. Geol., 53, 283-294. 
Petrin Z., Laudon H. and Malmqvist B., 2007. Does freshwater macroinvertebrate diversity along a pHgradient reflect adaptation to low pH? Fresh. Biol., 52, 2172-2183.

Pizarro J., Vergara P., Rodriguez J. and Valenzuela A., 2010. Heavy metals in northern Chilean rivers: Spatial variation and temporal trends. J. Hazard. M., 181, 747-754.

Pond G., Passmore M., Borsuk A., Reynolds L. and Rose J., 2008. Downstream effects of mountaintop coal mining: comparing biological conditions using genus- and family-level bioassessment tools. J. N. Am. Benthol. Soc., 27, 717-737.

Pond G.J., 2010. Patterns of Ephemeroptera taxa loss in Appalachian headwater streams (Kentucky, USA). Hydrobiologia, 641, 185-20.

Prat N., Munné A., Rieradevall M., Solà C. and Bonada N., 2000. ECOSTRIMED Protocol per determinar lèstat ecològic dels rius mediterranis. Diputació de Barcelona. Àrea de Medi Ambient., Barcelona.

Sánchez A. and Morales R., 1990. Las Regiones de Chile. Editorial Universitaria, Santiago.

Smolders A., Lock R., Van der Velde G., Medina-Hoyo R. and Roelofs J., 2003. Effects of mining activities on heavy metal concentrations in water, sediment and macroinvertebrates in different reaches of the Pilcomayo River, South America. Arch. Environ. Contam. Toxicol., 44, 314-323.

Strauch G., Oyarzún R., Reinstorf F., Oyarzun J., Schirmer M. and Knöller K., 2009. Interaction of water components in the semi-arid Huasco and Limarí river basins, North Central Chile. Adv. Geosci., 22, 51-57.

Tachet H., Richouxm P., Bournard M. and Usseglio P., 2003. Invertébrés d'eau douce : Systématique, biologie, écologie. CNRS editions, Paris.

Ter Braak C. and Smilauer P., 2002. CANOCO Reference manual and user's guide to CANOCO for windows: software for canonical community ordination (version 4). Microcomputer Power, Ithaca.

Thorp J. and Covich A., 2001. Ecology and classification of North American freshwater invertebrates. Second edition. Academic Press, San Diego.

Tokeshi M., 1995. Lyfe cycles and population dynamics. In: Armitage P., Cranston P. and Pinder L. (eds), The Chironomidae: biology and ecology of non-biting midges. Chapman and Hall, London.

Van Damme P., Hamel C., Ayala A. and Bervoits L., 2008. Macroinvertebrate community response to acid mine drainage in rivers of the High Andes (Bolivia). Environ. Pol., 156, 1061-1068.

Vila I. and Molina X., 2006. Manual de evaluación de la calidad del agua. Centro Nacional del Medio Ambiente CENMA, Santiago. 